\title{
A re-evaluation of recommended dietary allowances of calcium and phosphorus for pigs
}

By L. Gueguen and J. M. Perez, Station de Recherches de Nutrition and Station de Recherches sur l'Elevage des Porcs INRA, $7835^{\circ}$ fouy-en-Fosas, France

Among the various methods used to assess calcium and phosphorus requirements, only the factorial method seems to be scientifically satisfactory. Used for the first time in the pig by the Agricultural Research Council in 1967 , this method demands a good knowledge of net requirements (storage in weight gain and gestation products, secretion in milk, obligatory endogenous losses) and of the true absorption coefficient.

New results, acquired during the last 15 years by the use of radioisotopes, now provide a more solid theoretical basis for the use of this method, even if such problems (recently discussed by Partridge, 1980) as defining some net requirements (maintenance, growth) and the significance of the intestinal absorption coefficient cannot be underestimated.

Two recent attempts to reassess $\mathrm{Ca}$ and $\mathrm{P}$ requirements in pig have thus been reported by Mudd \& Stranks (1979) and Gueguen \& Perez (1979).

\section{Net requirements}

Net requirement for maintenance. This includes the inevitable endogenous losses in faeces and urine. We estimate a requirement of $35 \mathrm{mg} \mathrm{Ca} / \mathrm{kg}$ live weight per d (Hansard et al. 196r; Besançon \& Gueguen, 1969) of which $32 \mathrm{mg}$ is lost in the faeces. This value is nearly constant and close to that retained by the ARC (1967).

Values for $\mathrm{P}$ obtained by isotopic dilution are very few (Brüggemann et al. 1962; Cupak et al. 1972; Vemmer \& Oslage, 1973) and give a minimum endogenous loss in faeces varying from $5 \mathrm{mg} / \mathrm{kg}$ live weight per d with low-P diets to $15 \mathrm{mg} / \mathrm{kg}$ per $\mathrm{d}$ with normal diets. We estimate a mean value of $10 \mathrm{mg} / \mathrm{kg}$ per $\mathrm{d}$ endogenous faecal loss and $10 \mathrm{mg} / \mathrm{kg}$ per $\mathrm{d}$ urinary loss (Just, 1972; Jongbloed, 1978). These values exclude the 'surplus' component of the endogenous loss, corresponding to the excretion of $\mathbf{P}$ absorbed in excess of the needs.

Net requirement for growth. This corresponds to the daily storage of $\mathrm{Ca}$ and $\mathrm{P}$ needed for an optimal mineralization of the body-weight gain. This requirement thus varies according to the growth rate and the desired degree of bone mineralization. It is well known that the ash-content of the skeleton increases almost linearly in piglet with increasing $\mathrm{Ca}$ and $\mathrm{P}$ intakes (Blair \& Benzie, 1964), but it is certainly not necessary, in particular for pigs slaughtered at $100 \mathrm{~kg}$, to obtain the maximal mineralization.

The values adopted by the ARC ( 1967 ) diminished with age, from II $5 \mathrm{~g} \mathrm{Ca}$ and $9.0 \mathrm{~g} \mathrm{P}$ at $10 \mathrm{~kg}$ body-weight to $7.5 \mathrm{~g} \mathrm{Ca}$ and $5.0 \mathrm{~g} \mathrm{P}$ at $90 \mathrm{~kg}$ body-weight. In

-Present address: INRA Centre de Rennes-Saint-Gilles, 35590 l'Hermitage.

$0029-665^{1} / 81 / 4033^{-5503} \$ 01.00$ (c) 1981 The Nutrition Society 
Table I. Net requirements of $\mathrm{Ca}$ and $\mathrm{P}$ for growth ( $\mathrm{g} / \mathrm{kg}$ live-weight gain per $d$ )

\begin{tabular}{lccccccc}
\multicolumn{8}{c}{ Live wt (kg) } \\
$\mathrm{Ca}$ & $\overbrace{10}$ & 20 & 35 & 50 & 70 & 100 & $>_{100}$ \\
$\mathrm{P}$ & II & 10 & 10 & 9.5 & 9.0 & 8.0 & 7.0 \\
& 7.0 & 6.0 & 6.0 & 6.0 & 5.5 & 5.5 & 5.0
\end{tabular}

fact, the mineral composition of gain is more constant in meat-type, less fatty pigs, and may even increase in lean pigs (Günther \& Rosin, 1970).

Table I gives the mean daily retentions of $\mathrm{Ca}$ and $\mathrm{P} / \mathrm{kg}$ weight gain for pigs in French rearing conditions.

For the weight gain of sows during pregnancy (foetuses excluded), we are adopting $5 \mathrm{~g} \mathrm{Ca}$ and $3 \mathrm{~g} \mathrm{P} / \mathrm{kg}$ body-weight gain.

Net requirement for pregnancy. This is negligible during the first 2 months, the foetuses being mineralized mainly during the last third of pregnancy. The liquids and membranes contain very little $\mathrm{Ca}$ and $\mathrm{P}$. The body composition of the newborn piglet is now well known and the $\mathrm{Ca}$ and $\mathrm{P}$ contents are about 10 and $6 \mathrm{~g} / \mathrm{kg}$ body-weight (ARC, 1967; Mudd et al. 1969; Oslage, 1964; Günther et al. 1967).

Therefore, for a multiparous sow producing new-born piglets with a total weight of $12 \mathrm{~kg}$, the mean requirements are $3 \mathrm{~g} \mathrm{Ca}$ and $2 \mathrm{~g} \mathrm{P} / \mathrm{d}$ during the last five weeks of pregnancy. The corresponding values for a multiparous sow producing piglets with a total weight of $14 \mathrm{~kg}$ are $3.7 \mathrm{~g} \mathrm{Ca}$ and $2.2 \mathrm{~g} \mathrm{P} / \mathrm{d}$. This net requirement is only for the mineralization of the foetuses and must be added to the net requirement for the growth of the sow.

Net requirement for milk production. This is the amount of $\mathrm{Ca}$ and $\mathrm{P}$ secreted in milk. The average Ca and P contents of sow's mill are $2.2 \mathrm{~g} \mathrm{Ca}$ and $1.55 \mathrm{~g} \mathrm{P} / \mathrm{kg}$ respectively (Gueguen \& Salmon-Legagneur, 1959) which increase with the stage of lactation. During the 5 weeks of a classical lactation, the corresponding average values are $2.0 \mathrm{~g} \mathrm{Ca}$ and $\mathrm{I} .5 \mathrm{~g} \mathrm{P} / \mathrm{kg}$.

\section{True intestinal absorption}

The only information on Ca utilized in the ARC report was the results of Hansard et al. (1961) which overestimated the efficiency of absorption in the young pig weighing less than $45 \mathrm{~kg}$. No $\mathrm{P}$ utilization value obtained with ${ }^{32} \mathrm{P}$ was available.

$\mathrm{Ca}$. The values obtained for $\mathrm{Ca}$ with ${ }^{45} \mathrm{Ca}$ (Hansard et al. $\mathrm{r} 96 \mathrm{r}$; Besancon \& Gueguen, 1969; Whittemore et al. 1972; Atherton et al. 1975) show clearly that the true absorption of $\mathrm{Ca}$ varies between 0.45 and 0.55 , except for the very young animal, in which it can be higher than 0.60 . The pig is able to adapt the efficiency of $\mathrm{Ca}$ absorption to the level of $\mathrm{Ca}$ intake, and the absorption of a very low intake $(2 \mathrm{~g} / \mathrm{d})$ is higher than 0.80 (Pointillart \& Thomasset, 1979). Nevertheless, the minimum net requirement for a growing $30 \mathrm{~kg}$ pig being $6-7 \mathrm{~g} \mathrm{Ca} / \mathrm{d}$, the corresponding minimal dietary intake is necessarily higher than $7 \mathrm{~g} / \mathrm{d}$, leading to a 
true absorption coefficient of about $0.5^{\circ}$. True absorption depends on the absorption capacity of the intestine, which can adapt to a low intake, and on the availability of $\mathrm{Ca}$ in feed, which is often a limiting factor. So, under practical conditions, a good adaptation to the level of $\mathrm{Ca}$ intake cannot be expected.

$P$. The availability of $\mathrm{P}$ in pig feeds is probably more variable than that of $\mathrm{Ca}$ and has not been studied as much.

Several experiments using ${ }^{32} \mathrm{P}$ have shown that the true absorption coefficient of inorganic $P$ from good quality phosphates exceeds 0.65 (Gueguen \& Rerat, 1965; Gueguen, 1970; Cupak et al. 1972; Whittemore et al. 1972; Atherton et al. 1975).

On the contrary, it is surprising that there is almost no work on the true absorption of plant P. Only a few attempts have been made as, for example, that of Gueguen et al. (1968) which estimates the true absorption coefficient of phytic $\mathrm{P}$ of ${ }^{32}$ P-labelled wheat bran as about 0.35 . We thus have to use results on the apparent digestibility of $\mathbf{P}$ in diets containing only grains and oil-seed meals with no supplementary inorganic $P$. It is then possible, considering the low endogenous faecal losses $\left(5^{-10} \mathrm{mg} / \mathrm{kg}\right.$ per $\left.\mathrm{d}\right)$, to calculate true absorption coefficients.

Thus, the results gathered in the reviews of Peeler (1972), Nelson (1980) and Cromwell (1980) show that the true absorption coefficient of plant $P$ varies in the pig between 0.25 and 0.50 (mean value approximately $0.35-0.40$ ).

According to the detailed work done at the University of Kentucky, using bonebreaking strength as a criterion (Miracle et al. 1977; Stober et al. 1979; Cromwell, 1979, 1980), there appears to be a wide range in availability of $P$ among feed grains. Adopting a value of $I \cdot O$ for inorganic $P$ (which is overestimated), the mean biological availabilities are: wheat 0.48 ; barley 0.35 ; wheat bran 0.29 ; soya-bean meal 0.22 ; corn and sorghum 0.12 ; cotton-seed meal 0 . This classification is logical since it expresses the phytase richness of the feed (Nelson, r 980 ). The observations of Greer et al. (1978) showing that the incidence of broken bones and foot abnormalities was more marked in pigs given sorghum and maize than those given wheat and barley, also seem to confirm it. Likewise, we have recently shown (Gueguen and Bagheri, unpublished results) that true absorption coefficient of $P$ in a maize-soya-bean diet without added $P$, was increased from 0.36 to $0.4^{8}$ by introducing $20 \%$ wheat bran in the diet.

However, according to other results obtained by Bayley \& Thomson (1969), Bayley et al. (1975), Besecker et al. (1967), Vipperman et al. (1974), Pierce et al. (1977), Calvert et al. (1978) on the apparent absorption of only the diets with no supplementary inorganic $P$, the difference between wheat and barley, on the one hand, and maize, on the other, is not so obvious. Moreover, maize $\mathbf{P}$ digestibility seems to be improved by pelleting (Bayley \& Thomson, 1969; Bayley et al. 1975) or acidification (Abrams et al. 1975). Therefore, as already suggested (Gueguen et al. I 968 ), phytic $\mathbf{P}$ may be less utilizable than inorganic $\mathrm{P}$ for bone accretion or some products of the partial hydrolysis of phytic acid may be potent inhibitors of bone mineralization (Thomas \& Tilden, 1972; Van Den Berg et al. 1972).

Until more work is done in this field, we consider the true availability of inorganic $\mathrm{P}$ to be 0.70 and that of phytic $\mathrm{P} 0.35$, giving a mean value of 0.50 when 
supplementary $P$ is one-third of the total $P$ (phytic $P$ thus being one-half of the total $P$ ). This mean value agrees with the numerous results of balance trials using normal diets.

The recommended dietary allowances have been calculated on the basis of the true absorption coefficients given in Table 2. For lactating sows, we have adopted mean values of $0.5^{\circ}$ for $\mathrm{Ca}$ and 0.55 for $\mathrm{P}$.

\section{Proposed new recommendations}

The calculation of the recommendations given in Tables 3 and 4 has taken into account the preceding new theoretical bases and the usual practical rearing conditions in France (live weight, gain rate, milk yield, type of diet).

Table 2. True absorption coefficient of $\mathrm{Ca}$ and $\mathrm{P}$ in pigs of various live weights

\begin{tabular}{lccccc}
\multicolumn{6}{c}{ Live wt (kg) } \\
\cline { 4 - 6 } \\
$\mathrm{Ca}$ & 0.70 & 10 & 20 & 35 & $50-100$ \\
$\mathrm{P}$ & 0.60 & 0.50 & 0.55 & 0.50 & 0.45 \\
& 0.55 & 0.50 & 0.50 & 0.50
\end{tabular}

Table 3. Recommended dietary allowances of $\mathrm{Ca}$ and $\mathrm{P}$ for the piglet and the growing-finishing pig

\begin{tabular}{|c|c|c|c|c|c|c|c|}
\hline & & & & re wt & & & \\
\hline & 5 & ro & 20 & 35 & $5^{\circ}$ & 70 & 100 \\
\hline Gain $(g / d)$ & $25^{\circ}$ & $35^{\circ}$ & 500 & 600 & $75^{\circ}$ & 800 & 900 \\
\hline Diet ${ }^{\circ}$ consumed $(\mathrm{kg} / \mathrm{d})$ & 0.35 & 0.6 & I I I & $\mathrm{I} \cdot 6$ & $2 \cdot 1$ & $2 \cdot 5$ & 2.8 \\
\hline $\mathrm{Ca}(\mathrm{g} / \mathrm{d})$ & $4 \cdot 5$ & $7 \cdot 0$ & $10 \cdot 5$ & 15.0 & 20 & 21 & 24 \\
\hline$P(g / d)$ & 3.0 & 5.0 & $8 \cdot 0$ & $9 \cdot 5$ & I I & 12 & 14 \\
\hline $\mathrm{Ca}(\mathrm{g} / \mathrm{kg} \text { diet })^{*}$ & 13.0 & II. 5 & 9.5 & $9 \cdot 5$ & $9 \cdot 5$ & $8 \cdot 5$ & $8 \cdot 5$ \\
\hline$P(g / k g$ diet $)$ & 8.5 & $8 \cdot 0$ & 7.0 & 6.0 & $5 \cdot 0$ & $5 \cdot 0$ & $5 \cdot 0$ \\
\hline
\end{tabular}

Table 4. Recommended dietary allowances of $\mathrm{Ca}$ and $\mathrm{P}$ for the sow

\begin{tabular}{|c|c|c|c|}
\hline & $\begin{array}{c}\text { Maintenance and } \\
\text { first two-thirds of } \\
\text { pregnancy }\end{array}$ & $\begin{array}{l}\text { End of pregnancy } \\
\text { (last } 5 \text { weeks) }\end{array}$ & Lactation $\dagger$ \\
\hline Live wt $(\mathrm{kg})$ & $130-180$ & $160-200$ & $140-180$ \\
\hline Body-wt gain (g/d) & $400-300$ & $250-200$ & - \\
\hline $\begin{array}{l}\text { Diet }{ }^{\circ} \text { consumed }(\mathrm{kg} / \mathrm{d}) \\
\mathrm{Ca}(\mathrm{g} / \mathrm{d})\end{array}$ & $\begin{array}{l}2.5 \\
16 \cdot 0-17.5\end{array}$ & $\begin{array}{l}2 \cdot 5 \\
23-26\end{array}$ & $\begin{array}{c}4 \cdot 5-5 \cdot 0 \\
34-41\end{array}$ \\
\hline$P(g / d)$ & 9.0 & $12-14$ & $22-27$ \\
\hline $\begin{array}{l}\mathrm{Ca}(\mathrm{g} / \mathrm{kg} \text { diet })^{*} \\
\mathrm{P}(\mathrm{g} / \mathrm{kg} \text { diet })^{*}\end{array}$ & $\begin{array}{c}6 \cdot 5-7 \cdot 0 \\
4 \cdot 0\end{array}$ & $\begin{array}{l}9 \cdot 5^{-10} \cdot 5 \\
5 \cdot 0-5.5\end{array}$ & $\begin{array}{l}7 \cdot 5-8 \cdot 0 \\
5 \cdot 0-5 \cdot 5\end{array}$ \\
\hline
\end{tabular}

-Air-dry diet.

$\dagger$ First value for first pregnancy or lactation, second value for next pregnancies or lactations. 
For $\mathrm{Ca}$, these new recommended allowances are higher than those of the ARC (1967) and the NRC (1979) but are very close to the values recently calculated by Mudd \& Stranks (1979).

The low calculated values for $P$, mainly for growing-pigs after $50 \mathrm{~kg}(5 \mathrm{~g} / \mathrm{kg})$ and for sows (less than $5.5 \mathrm{~g} / \mathrm{kg}$ ), are in good agreement with the recommendations of the ARC and the NRC. Moreover, they are confirmed by numerous recent practical studies using bone criteria in growing-pigs (Cromwell et al. 1972; Stockland \& Blaylock, 1973; Pond et al. 1975; Doige et al. 1975; Bayley et al. 1975; Newman \& Elliott, 1976; Van Kempen et al. 1976) and in sows (Kornegay et al. 1973; Harmon et al. 1974, 1975; Tanksley, 1976).

The recent German recommendations for $\mathrm{Ca}$ and $\mathrm{P}$ (Gesellschaft für Ernährungsphysiologie der Haustiere, 1978) are higher than ours for sows and lower for growing pigs.

Higher levels of $\mathrm{Ca}$ and $\mathrm{P}$ are necessary to obtain maximal bone mineralization but are not essential, either for achieving maximal performance during the growing-finishing period, or to improve skeletal development and bone quality (Doige et al. 1975; Van Kempen et al. 1976; Bayley et al. 1975; Nimmo et al. 1980). Moreover, increasing the intakes of $\mathrm{Ca}$ and $\mathrm{P}$ above the present recommendations does not decrease the incidence of osteochondrosis or leg weakness (Stockland \& Blaylock, 1973; Pointillart \& Gueguen, 1978) and atrophic rhinitis (Nielsen et al. 1971; Cromwell et al. 1972; Stockland \& Blaylock, 1973) nor increase the fertility of sows (Frölich et al. 1974). Nevertheless, with other types of diets, for example with restricted feeding or high protein levels (Reinhard et al. 1976), higher concentrations of $\mathrm{Ca}$ and $\mathrm{P}$ in feed might be beneficial. Likewise, higher levels might be advised for boars, when the maximal bone breaking strength has to be achieved.

\section{REFERENCES}

Abrams, S. M., Wallace, H. D. \& Combs, G. F. (1975). F. Anim. Sci. 4I, 306 (abstr).

Agricultural Research Council (rg67). The Nutrient Requirements of Farm Livestock. No. 3. Pigs. London: HM Stationery Office.

Atherton, D., Thompson, A. \& Smith, W. C. (1975). Proc. Br. Soc. anim. Prod. 4, 116.

Bayley, H. S., Arthur, D., Bowman, G. H., Pos, J. \& Thomson, R. G. (1975). F. Anim. Sci. 40, 864 .

Bayley, H. S. \& Thomson, R. G. (1969). F. Anim. Sci. 28, 484.

Besançon, P. \& Gueguen, L. (1969). Ann. Biol. anim. Bioch. Biophys. 9, 537.

Besecker, R. J. Jr, Plumlee, M. P., Pickett, R. A. \& Conrad, J. N. (1967). F. Anim. Sci, 26, 4477. Blair, R. \& Benzie, D. (1964). Br. F. Nutr. 18, 91.

Brüggemann, J., Bronsch, K. \& Bootz, H. (1962). Z. Tierphysiol. Tierernähr. Futtermittelk. 17, 91 .

Calvert, C. C., Besecker, R. J., Plumlee, M. P., Cline, T. R. \& Forsyth, D. M. (1978). F. Anim. Sci. $47,420$.

Cromwell, G. L. (1979). Proc. Dist. Feed Res. Conf. 34, 40.

Cromwell, G. L. (1980). Feedstuffs 52, 38.

Cromwell, G. L., Hays, V. W., Scherer, C. W. \& Overfield, J. R. (1972). F. Anim. Sci. 34, 746. Cupak, M., Prochazka, Z. \& Jambor (r972). Acta Vet. Brno 4I, 257.

Doige, C. E., Owen, B. D. \& Mills, J. H. L. (1975). Can. F. Anim. Sci. 55, 147. 
Frölich, A., Simonsson, A., Thomke, S. \& Kronevi, T. (1974). Eur. Assoc. Anim. Prod. Copenhagen, D.K.

Gesellschaft für Ernährungsphysiologie der Haustiere. Ausschusz für Bedarfsnormen (1978). Empfehlungen zur Mineralstoffversorgung. Frankfurt: DLG-Verlag.

Greer, E. B., Lewis, C. E. \& O'Neill, G. H. (1978). Aust. F. exp. Agric. Anim. Husb. 18, 773. Gueguen, L. (1970). Bull. Soc. Sci. Hyg. alim. 58, 7-8-9, 115.

Gueguen, L., Besançon, P. \& Rerat, A. (1968). Ann. Biol. anim. Bioch. Biophys. 8, 273.

Gueguen, L. \& Perez, J. M. (1979). Eur. Assoc. Anim. Prod. Harrogate, G.B.

Gueguen, L. \& Rerat, A. (1965). C.R. Acad. Sci., Paris 260, 5 II 2.

Gueguen, L. \& Salmon-Legagneur, E. (1959). C.R. Acad. Sci., Paris 249, 784.

Günther, K. \& Rosin, G. (I970). Z. Tierphysiol. Tierernähr. Futtermittelk. 26, 179.

Günther, K., Witting, R. \& Lenkeit, W. (1967). Z. Tierphysiol. Tierernähr. Futtermittelk. 22, 298.

Hansard, S. L., Lyke, W. A. \& Crowder, H. M. (1961). J. Anim. Sci. 20, 292.

Harmon, B. G., Liu, C. T., Cornelius, S. G., Pettigrew, J. E., Baker, D. H., Jensen, A. H. (1974). 7. Anim. Sci. 39, III7.

Harmon, B. G., Liu, C. T., Jensen, A. H. \& Baker, D. H. (1975). F. Anim. Sci. 40, 660.

Jongbloed, A. W. (1978). Landbourvkd. Tijdschr. 90, 1 .

Just, A. (1972). Acta Agric. Scand. 22, 223.

Kornegay, E. T., Thomas, H. R. \& Meacham, T. N. (1973). f. Anim. Sci. 37, 494.

Miracle, G. L., Cromwell, G. L., Stahly, T. S. \& Kratzer, D. D. (r977). Abstr. A.S.A.S. 45, 101.

Mudd, A. J., Smith, W. C. \& Armstrong, D. G. (I969). f. Agric. Sci. 73, I8 1.

Mudd, A. J. \& Stranks, M. H. (1979). Eur. Assoc. Anim. Prod. Harrogate, G.B.

National Research Council (1979). Nutrient Requirements of Domestic Animals. No. 2, Nutrient Requirements of Swine, 8th ed. Washington DC: National Academy of Sciences.

Nelson, T. S. (1980). Proc. Florida Nutr. Conf. 59.

Newman, C. W. \& Elliott, D. O. (1976). F. Anim. Sci. 42, 92.

Nielsen, N. C., Andersen, S., Madsen, A. \& Mortensen, H. P. (1971). Acta Vet. Scand. 12, 202.

Nimmo, R. D., Peo, E. R. Jr, Moser, B. D., Cunningham, P. J., Olson, D. G. \& Crenshaw, T. D. (1980). F. Anim. Sci. 51, 100.

Oslage, H. J. (1964). Z. Tierphysiol. Tierernähr. Futtermittelk. 19, 330.

Partridge, I. G. (I980). Proc. Nutr. Soc. 39, 185.

Peeler, H. T. (1972). f. Anim. Sci. 35, 695 .

Pierce, A. B., Doige, C. E., Bell, J. M. \& Owen, B. D. (1977). Can. F. Anim. Sci. 57, 573.

Pond, W. G., Walker, E. F. Jr \& Kirtland, D. (1975). F. Anim. Sci. 41, 1053.

Pointillart, A. \& Gueguen, L. (1978). Ann. Biol. anim. Bioch. Biophys. 18, 201.

Pointillart, A. \& Thomasset, M. (1979). 14th Europ. Symp. Calc. Tiss. Rhodes.

Reinhard, M. K., Mahan, D. C., Workman, B. L., Cline, J. H., Fetter, A. W. \& Grifo, A. P. Jr (1976). F. Anim. Sci. 43, 770.

Stober, C. R., Cromwell, G. L. \& Stahly, T. S. (1979). Abstr. Midwest. Sect. A.S.A.S.

Stockland, W. L. \& Blaylock, L. G. (1973). F. Anim. Sci. 37, 906.

Tanksley, T. D. Jr (1976). Mineral Nutrition of the Sow. Proc. Swine Short Course. Texas Agric. Exp. Stn.

Thomas, W. C. \& Tilden, M. T. (1972). Fohn Hopkins Hosp. Bull. 131, 133.

Van Den Berg, C. J., Hill, L. F. \& Stanburg, S. W. (1972). Clin. Sci. 43, 377.

Van Kempen, G. J. M. (1976). Neth. F. Agric. Sci. 24, 120.

Vemmer, H. \& Oslage, H. J. (I973). Z. Tierphysiol. Tierernähr. Futtermittelk. 31, I 29.

Vipperman, P. E. Jr, Peo, E. R. Jr \& Cunningham, P. J. (1974). F. Anim. Sci. 38, 758.

Whittemore, C. T., Smith, W. C. \& Thompson, A. (1972). Anim. Prod. 15, 265. 